\title{
PARTISIPASI MASYARAKAT DALAM PENGELOLAAN DANA DESA PADA DESA CITAMAN JERNIH KECAMATAN PERBAUNGAN KABUPATEN SERDANG BEDAGAI
}

\author{
Ferry Setiawan $^{1)}$, Bhayu Rhama ${ }^{2)}$ \\ 1) Jurusan Ilmu Administrasi Negara, Fakultas Ilmu Sosial dan Politik, Universitas Palangka \\ Raya, Indonesia \\ 2) Jurusan Ilmu Administrasi Negara, Fakultas Ilmu Sosial dan Politik, Universitas Palangka \\ Raya, Indonesia \\ *Email Korespondensi : setiawan.ferry36@fisip.upr.ac.id
}

\begin{abstract}
Abstrak
Pada penelitian ini mengkaji partisipasi masyarakat pada pengelolaan Dana Desa dan Alokasi Dana Desa pada wilayah Desa Citaman Jernih yang merupakan salah satu desa yang ada di Kecamatan Perbaungan Kabupaten Serdang Badagai yang telah menerima Dana Desa. Pada penelitian ini menggunakan metode penelitian kualitatif deskriptif dengan teknik pengumpulan data melalui observasi, wawancara dan studi dokumentasi di Desa Citaman Jernih. Teknik penentuan informan menggunakan teknik purposive untuk melacak variasi informasi yang dimungkinkan ada. Adapun Teknik analisa data yang digunakan dalam penelitian ini adalah analisa dengan menggunakan model interaktif (interactive models of analysis). Hasil penelitian ini mengemukanan bahwa partisipasi masyarakat dalam pengelolaan dana desa belum terlaksana dengan baik.
\end{abstract}

Kata Kunci: Partisipasi; Dana Desa

\begin{abstract}
This research examines community participation in the management of Village Funds and Village Fund Allocation in the Citaman Jernih Village area, which is one of the villages in Perbaungan District, Serdang Badagai Regency that has received Village Funds. In this study using descriptive qualitative research methods with data collection techniques through observation, interviews and documentation studies in Citaman Jernih Village. The technique of determining informants uses a purposive technique to trace the variations in information that may exist. The data analysis technique used in this research is analysis using interactive models (interactive models of analysis). The results of this study suggest that community participation in the management of village funds has not been implemented properly.
\end{abstract}

Keywords: Participation; Village Fund 


\section{PENDAHULUAN}

Pelaksanaan otonomi daerah di Indonesia sudah diselenggarakan lebih dari satu dasawarsa. Otonomi daerah untuk pertama kali mulai diberlakukan di Indonesia melalui Undang-Undang Nomor 22 Tahun 1999 tentang Pemerintah Daerah yang didalamnya juga mengatur tentang Pemerintah Desa, kemudian direvisi menjadi Undang-Undang 32 Tahun 2004 dan direvisi kembali menjadi Undang-Undang Nomor 23 Tahun 2014.

Partisipasi masyarakat sangat penting dalam pengambilan dan pengelolaan keuangan desa, hal ini menjadi pertimbangan kebijakan yang dilakukan oleh pemerintah desa dalam mengelola keuangan desa (Subekti, 2014). Partisipasi masyarakat tentu bukan hanya sebagai omongan belaka, juga dilakukan keikutsertaan untuk mengelola keuangan desa yang lebih baik dan maju. Pemerintah desa juga harus melibatkan masyarakat setempat agar asas keadilan dan penggunaan dana desa tepat sasaran. Namun seringkali hal ini menjadi permasalah antara masyrakat desa dan pemeritah desa sehingga menimbulkan permasalahan antara kedua belah pihak. Hal inilah yang menjadi menarik dalam penelitian ini, ingin melihat bagaimana kedua pihak ini sama-sama saling melibatkan(Kartika, 2012).

Pembangunan partisipatif harus dimulai dengan masyarakat sebagai manusia yang memiliki aspirasi dan paling mengetahui tentang kebutuhanya (Kartika, 2012). Masyarakat adalah pelaku utama pembangunan dan pemerintah daerah harus dapat memposisikan diri sebagai fasilitator untuk menciptakan suasana yang menjunjung kegiatan masyarakat yang di harapkan dapat mendukung dan tujuan pemerintah yang dilakukan melalui partisipasi masyarakat (Setiawan \& Saefulloh, 2019).

Partisipasi masyarakat merupakan salah satu penentu bagi keberhasilan pelaksanaan pembangunan. Dilain pihak bahwa pembangunan desa atau kelurahan diarahkan pada kewajiban antara pemerintah dan masyarakat. Bahkan di dalam pokok-pokok kebijaksanaan pembangunan desa dirumuskan bahwa mekanisme pembangunan desa atau kelurahan adalah merupakan perpaduan yang harmonis dan serasi antara dua kelompok kegiatan utama yaitu berbagai kegiatan pemerintah sebagai kelompok kegiatan pertama dan berbagai kegiatan partisipasi masyarakat sebagai kelompok utama yang kedua. Dalam pasal 78 UU NO 6 Tahun 2014 dijelaskan bahwa pembangunan desa bertujuan untuk 
meningkatkan kesejahteraan masyarakat desa dan kualitas hidup manusia serta penanggulangan kemiskinan melalui pemenuhan kebutuhan dasar, pembangunan sarana dan prasarana desa, pengembangan potensi ekonomi lokal serta pemanfaatan sumber daya alam dan lingkungan secara berkelanjutan. Dijelaskan pada bagian ketiga bahwa dalam pembangunan desa harus mengedepankan kebersamaan, kekeluargaan, dan kegotong royongan guna mewujudkan perdamaian dan keadilan sosial (Sembel et al., 2017).

Pada penelitian ini mengkaji partisipasi masyarakat pada pengelolaan Dana Desa dan Alokasi Dana Desa pada wilayah Desa Citaman Jernih yang merupakan salah satu desa yang ada di Kecamatan Perbaungan Kabupaten Serdang Badagai yang telah menerima Dana Desa. Desa Citaman Jernih, Kecamatan Perbaungan, Kabupaten Sergei menerima Dana Desa sejak tahun 2015 setelah berlakunya Undang-Undang Nomor 6 tahun 2014 tentang Desa, dan sejak 2 tahun anggaran terakhir (2019-2020), Desa Citaman Jernih telah menerima dana desa di atas 1 milyar rupiah (Lubis, 2020).

Pada tahun 2019 Desa Citamana Jernih menerima Alokasi Dana Desa dan Dana Desa sebesar Rp. 1.071.199.183,-; yang digunakan untuk peningkatan infrastruktur di desa berupa pembuatan rabat beton, rehab rabat beton, dan pembuatan parit. Sedangkan pada tahun 2020 Desa Citaman Jernih menerima Alokasi Dana Desa dan Dana Desa sebesar Rp. 1.261.645.155,-; dengan rincian Alokasi Dana Desa sebesar Rp. 801.728.088,dan Dana Desa sebesar Rp. 399.041.391,- yang digunakan untuk bidang pembangunan dan bidang pemberdayaan masyarakat. Dibidang pembangunan, pemerintah Desa Citaman Jernih, Kecamatan Perbaungan, Kabupaten Sergei melaksanakan pembangunan parit, rabat beton, pembuatan gapura. Sedangkan pada bidang pemberdayaan masyarakat, pemerintah Desa Citaman Jernih melaksanakan pelatihan pemerintahan desa, peningkatan kesehatan masyarakat, gotong royong masyarakat, penyuluhan tentang bahaya narkoba, sosialissi Bumdes dan penyuluhan/pemeriksaan kesehatan (Lubis, 2020).

Sebagai contoh di Desa Citaman Jernih masih terdapat ketidakmampuan Penanggungjawab Kegiatan (PK) dalam mengelola keuangan desa, yang mana Penanggungjawab Kegiatan tersebut diambil dari Tokoh dan Unsur Lembaga Masyarakat. Selain itu, masih terdapat ketidakemampuan Tim Pelaksana Kegiatan (TPK) dalam menyusun rincian kegiatan. Penyusunan kegiatan masih sering mengalami keterlambatan 
karena banyaknya urusan yang mesti diurus oleh Tim Pelaksana Kegiatan (TPK) sehingga pada saat akan melaksanakan kegiatan ada keterlambatan pencairan dana dari pemerintah desa.

Permasalahan lain adalah yang paling mencolok adalah belum adanya aktivitas transparansi yang dilakukan seperti pemberitahuan ke masyarakat desa, belum ada papan informasi dan baliho terkait dengan pengelolaan keuangan desa. Padahal seperti yang telah diketahui dalam Undang-undang tentang desa tertulis bahwa Pemerintah Desa wajib memberikan informasi secara massif kepada masyarakat. Melihat beberapa permasalahan diatas penulis tertarik untuk mengetahui Partisipasi Masyarakat Dalam Pengelolaan Dana Desa pada Desa Citaman Jernih Kabupaten Serdang Bedagai.

\section{TINJAUAN PUSTAKA}

Definisi partisipasi menurut Kamus Besar Bahasa Indonesia (KBBI) partisipasi ialah perihal turut berperan serta dalam suatu kegiatan, keikutsertaan dan peran serta. Sedangkan menurut Tjokroamidjoyo dalam (Sembel et al., 2017) menegaskan bahwa partisipasi adalah keterlibatan masyarakat dalam penentuan arah, strategi dan kebijaksanaan pembangunan yang dilakukan oleh pemerintah. Keterlibatan masyarakat dalam memikul beban dan dalam memetik hasil atau manfaat pembangunan adalah suatu partisipasi masyarakat.

Made Pidarta dalam (Andi Uceng \& , Ahmad Mustanir, 2019) menyatakan partisipasi adalah pelibatan seseorang atau beberapa orang dalam sesuatu kegiatan. Keterlibatan dapat berupa keterlibatan mental dan emosi serta fisik dalam menggunakan segala kemampuan yang dimilikinya (berinisiatif) dalam segala kegiatan yang dilaksanakan serta mendukung pencapaian tujuan dan tanggungjawab atas segala keterlibatan.

Naryan (1995) dalam (Dwiningrum, 2011) mengatakan partisipasi adalah keterlibatan emosi dan mental dari seseorang di dalam situasi kelompok yang mendorong mereka untuk menyokong kepada pencapaian tujuan kelompok tersebut dan ikut bertanggungjawab terhadap kelompoknya. Pendapat lain menjelaskan bahwa partisipasi merupakan penyertaan pikiran dan emosi dari pekerja kedalam situasi kelompok yang 
bersangkutan dan ikut bertanggungjawab atas kelompok itu. Partisipasi juga memiliki pengertian "a valeuntary process by which people including disadvantaged (income, gender,ethnicity, education) influence or control the affect them", artinya suatu proses yang wajar dimana masyarakat termasuk yang kurang beruntung (penghasilan, gender, suku, pendidikan) mempengaruhi atau mengendalikan pengambilan keputusan yang berlangsung menyangkut hidup mereka.

Huneryear dan Heoman dalam (Dwiningrum, 2011) menyatakan partisipasi adalah sebagai keterlibatan mental emosional dalam situasi kelompok yang mendorongnya memberi sumbangan terhadap tujuan kelompok serta membagi tanggungjawab bersama mereka. Partisipasi adalah sebagai wujud dari keinginan untuk mengembangkan demokrasi melalui proses desentralisasi dimana diupayakan antara lain perlunya perencanaan dari bawah (bottom-up) dengan mengikut sertakan masyarakat dalam proses perencanaan dan pembangunan masyarakatnya (Tilaar, 2009).

Partisipasi adalah keikutsertaan masyarakat dalam proses pengedentifikasian masalah dan potensi yang ada di masyarakat, pemilihan dan pengambilan keputusan tentang alternatif solusi untuk menangani masalah, pelaksanaan upaya mengatasi masalah, dan keterlibatan masyarakat dalam proses mengevaluasi perubahan yang terjadi (Nurwanda, 2018).

Pentingnya partisipasi sebagai berikut: Pertama, partisipasi masyarakat merupakan suatu alat guna memperoleh informasi mengenai, kondisi, kebutuhan, dan sikap masyarakat setempat, yang tanpa kehadirannya program pembangunan serta proyek-proyek akan gagal; Kedua, bahwa masyarakat akan lebih mempercayai proyek atau program pembangunan jika merasa dilibatkan dalam proses persiapan dan perencanaannya, karena mereka akan lebih mengetahui seluk-seluk proyek tersebut dan akan mempunyai rasa memiliki terhadap proyek tersebut; Ketiga, bahwa merupakan suatu hak demokrasi bila masyarakat dilibatkan dalam pembangunan masyarakat mereka sendiri (Conyers, 1994).

Beberapa prinsip partisipasi yang dibentuk oleh Departemen for International Development (DFID) mengenai panduan pendekatan pelaksanaan partisipatif menurut Sumampouw dalam (Normina, 2016), yaitu: 
1. Cakupan. Semua orang atau sekelompok orang yang terkena dampak dari hasil suatu kebijakan pembangunan.

2. Kesetaraan dan kemitraan. Setiap orang memiliki kemampuan, keterampilan dan prakarsa serta mempunyai hak untuk menggunakan prakarsa tersebut dalam setiap proses untuk membangun dialog tanpa memperhitungkan jenjang struktur masingmasing pihak.

3. Transparansi. Setiap elemen masyarakat harus menumbuh kembangkan komunikasi dan iklim komunikasi yang terbuka dan kondusif sehingga menimbulkan dialog dua arah.

4. Kesetaraan dan kewenangan. Setiap pihak yang terlibat harus dapat menyeimbangkan pendelegasian kewenangan dan kekuasaan agar tidak terjadi dominasi.

5. Kesetaraan tanggung jawab. Setiap pihak memiliki tanggung jawab yang jelas dalam setiap proses karena adanya kesetaraan kewenangan dan keterlibatannya dalam setiap proses pengambilan keputusan.

6. Pemberdayaan. Keterlibatan seluruh elemen masyarakat tidak terlepas dari kelebihan dan kekurangannya, sehingga melalui keterlibatan aktif dalam setiap kegiatan terjadi suatu proses saling belajar dan memberdayakan.

7. Kerjasama. Diperlukan adanya kerjasama berbagai pihak yang terlibat untuk saling terlepas dari kelebihan untuk mengurangi berbagai kelemahan yang ada khususnya yang berkaitan dengan peningkatan sumber daya manusia.

Selain dari prinsip partisipasi maka salahsatunya adalah tahapan partisipasi. Tahapan partisipasi menurut Tjokroamidjoyo dalam (Sembel et al., 2017) dibagi menjadi 3 tahapan, yaitu:

1. Partisipasi atau keterlibatan dalam proses penentuan arah, strategi dan kebijaksanaan pembangunan yang dilakukan pemerintah.

2. Keterlibatan dalam memikul beban dan tanggungjawab dalam pelaksanaan kegiatan pembangunan.

3. Keterlibatan dalam memetik dan manfaat pembangunan secara berkeadilan. 
Selain tahapan partisipasi maka partisipasi dibedakan menjadi empat jenis yang akan menjadi teori utama pada penelitian ini. Menurut (Cohen \& Uphoff, 1977), membedakan partisipasi menjadi empat jenis, yaitu:

1. Participation in Decision Making adalah partisipasi masyarakat dalam proses pembuatan keputusan dan kebijakan organisasi. Partisipasi dalam bentuk ini berupa pemberian kesempatan kepada masyarakat dalam mengemukakan pendapatnya untuk menilai suatu rencana atau program yang akan ditetapkan. Masyarakat juga diberikan kesempatan untuk menilai suatu keputusan atau kebijaksanaan yang sedang berjalan. Partisipasi dalam pembuatan keputusan adalah proses dimana prioritas-prioritas pembangunan dipilih dan dituangkan dalam bentuk program yang disesuaikan dengan kepentingan masyarakat. Dengan mengikutsertakan masyarakat secara tidak langsung mengalami latihan untuk menentukan masa depannya sendiri secara demokratis.

2. Participation in Implementation adalah partisipasi atau keikutsertaan masyarakat dalam kegiatan operasional pembangunan berdasarkan program yang telah ditetapkan. Dalam pelaksanaan program pembangunan, bentuk partisipasi masyarakat dapat dinilai dari jumlah (banyaknya) yang aktif dalam berpartisipasi, bentuk-bentuk yang dipartisipasikan misalnya tenaga, bahan, uang, semuanya atau sebagian-sebagian, partisipasi langsung atau tidak langsung, semangat berpartisipasi, sekali-kali atau berulang-ulang.

3. Participation in Benefit adalah partisipasi masyarakat dalam menikmati atau memanfaatkan hasil-hasil pembangunan yang dicapai dalam pelaksanaan pembangunan.

4. Participation in Evaluation adalah partisipasi masyarakat dalam bentuk keikutsertaan menilai serta mengawasi kegiatan pembangunan serta hasilhasilnya. Penilaian ini dilakukan secara langsung, misalnya dengan ikut serta dalam mengawasi dan menilai atau secara tidak langsung, misalnya memberikan sara-saran, kritikan atau protes.

\section{METODE PENELITIAN}


Penelitian ini dilakukan dengan menggunakan metode penelitian kualitatif deskriptif dengan teknik pengumpulan data melalui observasi, wawancara dan studi dokumentasi di Desa Citaman Jernih. Teknik penentuan informan menggunakan teknik purposive bertujuan memperluas deskripsi informasi dan melacak variasi informasi yang dimungkinkan ada, juga untuk mengetahui dan mengulas lebih dalam mengenai Partisipasi Masyarakat Dalam Pengelolaan Dana Desa ada Desa Citaman Jernih Kabupaten Serdang Bedagai antar stakeholder di Desa Citaman Jernih. Adapun Teknik analisa data yang digunakan dalam penelitian ini adalah analisa dengan menggunakan model interaktif (interactive models of analysis).

\section{HASIL DAN PEMBAHASAN}

Dana Desa adalah dana APBN yang diperuntukkan bagi Desa yang ditransfer melalui APBD kabupaten/kota dan diprioritaskan untuk pelaksanaan pembangunan dan pemberdayaan masyarakat desa. Berdasarkan Undang-Undang Nomor 6 Tahun 2016 Tentang Desa, desa diberikan kewenangan untuk mengatur dan mengurus kewenangannya sesuai dengan kebutuhan. Hal itu berarti dana desa akan digunakan untuk mendanai keseluruhan kewenangan desa sesuai dengan kebutuhan dan prioritas dana desa tersebut. Dana desa merupakan dana yang bersumber dari anggaran pendapatan dan belanja negara yang diperuntukkan bagi desa yang di transfer melalui anggaran pendapatan dan belanja daerah kabupaten/kota dan digunakan untuk membiayai penyelenggaraan pemerintahan, pelaksanaan pembangunan, pembinaan kemasyarakatan dan pemberdayaan masyarakat. Pemerintah menganggarkan dana desa secara nasional dalam APBN (Anggaran Pendapatan dan Belanja Negara) setiap tahunnya yang bersumber dari belanja pemerintah dengan mengefektifkan program yang berbasis desa secara merata dan berkeadilan.

Partisipasi masyarakat desa Citaman Jernih dalam pembangunan desa dan pemberdayaan masyarakat. partisipasi adalah keikutsertaan masyarakat dalam proses pengedentifikasian masalah dan potensi yang ada di masyarakat, pemilihan dan pengambilan keputusan tentang alternatif solusi untuk menangani masalah, pelaksanaan 
upaya mengatasi masalah, dan keterlibatan masyarakat dalam proses mengevaluasi perubahan yang terjadi (Nurwanda, 2018).

Pentingnya partisipasi sebagai berikut: Pertama, partisipasi masyarakat merupakan suatu alat guna memperoleh informasi mengenai, kondisi, kebutuhan, dan sikap masyarakat setempat, yang tanpa kehadirannya program pembangunan serta proyek-proyek akan gagal; Kedua, bahwa masyarakat akan lebih mempercayai proyek atau program pembangunan jika merasa dilibatkan dalam proses persiapan dan perencanaannya, karena mereka akan lebih mengetahui seluk-seluk proyek tersebut dan akan mempunyai rasa memiliki terhadap proyek tersebut; Ketiga, bahwa merupakan suatu hak demokrasi bila masyarakat dilibatkan dalam pembangunan masyarakat mereka sendiri (Conyers, 1994).

Menurut (Mardiasmo, 2002) ada tiga prinsip utama yang mendasari pengelolaan keuangan desa, yaitu sebagai berikut:

a. Prinsip transparansi atau keterbukaan. Transparansi di sini memberikan arti bahwa anggota masyarakat memiliki hak dan akses yang sama untuk mengetahui proses anggaran karena menyangkut aspirasi dan kepentingan masyarakat, terutama pemenuhan kebutuhan-kebutuhan hidup masyarakat banyak.

b. Prinsip akuntabilitas. Akuntabilitas adalah prinsip pertanggungjawaban publik yang berarti bahwa proses penganggaran mulai dari perencanaan, penyusunan dan pelaksanaan harus benar-benar dapat dilaporkan dan dipertanggungjawabkan kepada DPRD dan masyarakat. Masyarakat tidak hanya memiliki hak untuk mengetahui anggaran tersebut tetapi juga berhak untuk menuntut pertanggungjawaban atas rencana ataupun pelaksanaan anggaran tersebut.

c. Prinsip value for money. Prinsip ini berarti diterapkannya tiga pokok dalam proses penganggaran yaitu ekonomis, efesiensi, dan efektif. Ekonomi berkaitan dengan pemilihan dan penggunaan sumber daya dalam jumlah dan kualitas tertentu pada harga yang murah. Efesiensi berarti bahwa penggunaan dana masyarakat tersebut dapat menghasilkan output yang maksimal atau mencapai target-target dan tujuan kepentingan publik

Dilihat dari empat jenis yang akan menjadi teori utama pada penelitian ini. 
Menurut (Cohen \& Uphoff, 1977), membedakan partisipasi menjadi empat jenis, yaitu:

1. Participation in Decision Making adalah partisipasi masyarakat dalam proses pembuatan keputusan dan kebijakan organisasi. Partisipasi dalam bentuk ini berupa pemberian kesempatan kepada masyarakat dalam mengemukakan pendapatnya untuk menilai suatu rencana atau program yang akan ditetapkan.

Dalam hal ini Desa Citaman Jernih melaksanakan pembangunan Desa baik fisik dan non fisik serta pemberdayaan masyarakat desa yang melibatkan partisipasi masyarakat dalam pembuatan keputusan yang dibuktikan dengan :

a. kehadiran rapat, dimana masyarakat yang dipilih oleh perangkat desa untuk hadir dalam rapat dan dibuktikan dengan daftar hadir.

b. diskusi, dimana masyarakat ikut berdiskusi dan dibuktikan dengan hasil notulen.

c. sumbangan pemikiran, adanya masukan yang diberikan oleh masyarakat.

d. tanggapan atau penolakan terhadap program yang ditawarkan, dimana masyarakat memberi dukungan dalam pembuatan keputusan dalam pembangunan fisik dan non fisik pada Desa Citaman Jernih.

Maka dalam hal ini Masyarakat Desa Citaman Jernih telah ikut partisipasi dan juga diberikan kesempatan untuk menilai suatu keputusan atau kebijaksanaan yang sedang berjalan. Partisipasi dalam pembuatan keputusan adalah proses dimana prioritas-prioritas pembangunan dipilih dan dituangkan dalam bentuk program yang disesuaikan dengan kepentingan masyarakat. Dengan mengikutsertakan masyarakat secara tidak langsung mengalami latihan untuk menentukan masa depannya sendiri secara demokratis untuk menentukan penggunaan dana desanya.

2. Participation in Implementation adalah partisipasi atau keikutsertaan masyarakat dalam kegiatan operasional pembangunan berdasarkan program yang telah ditetapkan.

Dalam hal ini partisipasi masyarakat Desa Citaman Jernih melaksanakan 
pembangunan Desa baik fisik dan non fisik serta pemberdayaan masyarakat desa yang melibatkan partisipasi masyarakat dalam dalam kegiatan operasional pembangunan berdasarkan program yang telah ditetapkan yang dibuktikan dengan :

1. menggerakkan sumber daya, dalam hal ini masyarakat desa dalam tidak ikut serta dalam pembangunan Desa baik fisik dan non fisik dikarenakan proses pembangunan fisik maupun non fisik sudah ditentukan ke pihak ke tiga baik kontraktor dan penyuluh dalam pemberdayaan masyarakat khususnya masyarakat yang ikut dalam PKK, Karang Taruna serta anggota BumDes.

2. dana, dalam hal ini masyarakat desa dalam tidak ikut serta dalam pembangunan Desa baik fisik dan non fisik dikarenakan proses pembangunan fisik maupun non fisik serta pemberdayaan masyarakat menggunakan dana desa.

3. kegiatan administrasi, dalam hal ini masyarakat desa dalam tidak ikut serta dalam pembangunan Desa baik fisik dan non fisik dikarenakan proses pembangunan fisik maupun non fisik serta pemberdayaan masyarakat dikerjakan oleh perangkat desa.

4. koordinasi dan penjabaran program, dalam hal ini masyarakat desa dalam tidak ikut serta dalam pembangunan Desa baik fisik dan non fisik dikarenakan proses pembangunan fisik maupun non fisik serta pemberdayaan masyarakat dikerjakan oleh satuan kerja desa secara menyeluruh.

Maka dapat dikatakan Dalam pelaksanaan program pembangunan, bentuk partisipasi masyarakat tidak aktif dalam berpartisipasi, sedangkan untuk pemerdayaan masyarakat sebagian-sebagian ikut partisipasi langsung atau tidak langsung baik ada yang sekali-kali atau berulang-ulang.

3. Participation in Benefit adalah partisipasi masyarakat dalam menikmati atau memanfaatkan hasil-hasil pembangunan yang dicapai dalam pelaksanaan pembangunan. 
Dalam hal ini partisipasi masyarakat Desa Citaman Jernih melaksanakan pembangunan Desa baik fisik dan non fisik serta pemberdayaan masyarakat desa yang melibatkan partisipasi masyarakat dalam menikmati atau memanfaatkan hasil-hasil yang dibuktikan dengan :

a. kuantitas (banyaknya) dari hasil program yang dikerjakan maupun dapat dilihat seberapa besar keberhasilan program, yang dibuktikan dengan pembangunan parit, rabat beton, pembuatan gapura. Sedangkan pada bidang pemberdayaan masyarakat, pemerintah Desa Citaman Jernih melaksanakan pelatihan pemerintahan desa, peningkatan kesehatan masyarakat, gotong royong masyarakat, penyuluhan tentang bahaya narkoba, sosialisasi Bumdes dan penyuluhan/pemeriksaan kesehatan.

b. kualitas dari hasil program yang dikerjakan atau Dari segi kualitas, dapat dilihat dari peningkatan output, yang dibuktikan dengan masih kokohnya pembangunan parit, rabat beton, pembuatan gapura yang ada di dudun IV Desa Citaman Jernih. Sedangkan pada program pemberdayaan masyarakat bertambahnya pemahaman masyarakat terkait pemerintahan desa, bahyanya NARKOBA.

4. Participation in Evaluation adalah partisipasi masyarakat dalam bentuk keikutsertaan menilai serta mengawasi kegiatan pembangunan serta hasilhasilnya.

Dalam hal ini partisipasi masyarakat Desa Citaman Jernih melaksanakan pembangunan Desa baik fisik dan non fisik serta pemberdayaan masyarakat desa yang melibatkan pa partisipasi masyarakat dalam menikmati atau memanfaatkan hasil-hasil belum dapat dibuktikan baik secara langsung atau secara tidak langsung baik berupa saran - saran, kritikan atau protes dari seluruh kegiatan pembangunan Desa baik fisik dan non fisik serta pemberdayaan masyarakat yang ada di Desa Citaman Jernih.

\section{KESIMPULAN DAN SARAN}


Berdasarkan hasil pembahasan diatas maka dapat disimpulkan bahwa Partisipasi Masyarakat Dalam Pengelolaan Dana Desa pada Desa Citaman Jernih Kabupaten Serdang Bedagai dilihat dari teori utama pada penelitian ini adalah sebagai berikut :

1. Participation in Decision Making adalah partisipasi masyarakat dalam proses pembuatan keputusan dan kebijakan organisasi Desa baik fisik dan non fisik serta pemberdayaan masyarakat telah terlaksana dan berjalan namun demikian keterlibatan masyarakat masih sebatas orang - orang yang dipilih oleh perangkat desa dan kepala desa..

2. Participation in Implementation adalah partisipasi atau keikutsertaan masyarakat dalam kegiatan operasional pembangunan Desa baik fisik dan non fisik serta pemberdayaan masyarakat berdasarkan program yang telah ditetapkan belum terlaksana, dimana seluruh pengerjaan dilakukan oleh pihak ketiga dalam hal ini kontraktor pada operasional pembangunan dan konsultan pada pemberdayaan masyarakat.

3. Participation in Benefit adalah partisipasi masyarakat dalam menikmati atau memanfaatkan hasil-hasil pembangunan yang dicapai dalam pelaksanaan pembangunan Desa baik fisik dan non fisik serta pemberdayaan masyarakat desa yang melibatkan partisipasi masyarakat dalam menikmati atau memanfaatkan hasil-hasil sudah berjalan dan terlaksana dengan baik.

4. Participation in Evaluation adalah partisipasi masyarakat dalam bentuk keikutsertaan menilai serta mengawasi kegiatan pembangunan serta hasilhasilnya belum dapat dibuktikan baik secara langsung atau secara tidak langsung baik berupa saran - saran, kritikan atau protes dari seluruh kegiatan pembangunan Desa baik fisik dan non fisik serta pemberdayaan masyarakat yang ada di Desa Citaman Jernih.

Berdasarkan hasil penelitian, pembahasan serta kesimpulan yang telah dikemukakan diatas berikut ini adalah Saran dari peneliti antara lain :

1. Dalam proses pembuatan keputusan dan kebijakan organisasi Desa baik fisik dan non fisik serta pemberdayaan masyarakat diharapkan mengundang seluruh 
masyarakat Desa Citaman Jernih agar hadir pada rapat pembuatan keputusan dan kebijakan organisasi Desa baik fisik dan non fisik serta pemberdayaan masyarakat agar aspirasi masyarakat dapat tertampung.

2. Dalam kegiatan operasional pembangunan Desa baik fisik dan non fisik serta pemberdayaan masyarakat berdasarkan program yang telah ditetapkan diharapkan seluruh pengerjaan dilakukan oleh pihak masyarakat baik kontraktornya maupun pekerjanya.

3. Dalam bentuk keikutsertaan menilai serta mengawasi kegiatan pembangunan serta hasil-hasilnya diharapkan agar melakukan monito dan evaluasi bersama masyarakat desa terkait seluruh kegiatan pembangunan Desa baik fisik dan non fisik serta pemberdayaan masyarakat yang ada di Desa Citaman Jernih agar mendapatkan berupa saran - saran, kritikan atau protes dari masyarakat Desa Citaman Jernih.

\section{REFERENSI}

Andi Uceng, A. A., \& , Ahmad Mustanir, N. (2019). Analisis Tingkat Partisipasi Masyarakat Terhadap Pembangunan Sumber Daya Manusia Di Desa Cemba Kecamatan Enrekang Kabupaten Enrekang. Moderat, 5(2), 1-17.

Cohen, \& Uphoff. (1977). Rural Development Participation. Cornel University.

Conyers, D. (1994). Perencanaan Sosial di Dunia Ketiga: Suatu Pengantar. Gadjah Mada University Press.

Dwiningrum, S. I. A. (2011). Desentralisasi dan Partisipasi Masyarakat dalam Pendidikan. Pustaka Pelajar.

Kartika, R. S. (2012). Partisipasi Masyarakat Dalam Mengelola Alokasi Dana Desa (Add) Di Desa Tegeswetan Dan Desa Jangkrikan Kecamatan Kepil Kabupaten Wonosobo. Bina Praja, 4(3), 179-188.

Lubis, L. (2020). Laporan Keuangan Desa.

Mardiasmo. (2002). Otonomi dan Manajemen Keuangan Daerah. . Penerbit Andi. Normina. (2016). Partisipasi Masyarakat Dalam Pendidikan. Kopertais Wilayah XI Kalimantan, 14(26), 71-85. 
Nurwanda, A. (2018). Partisipasi Masyarakat Dalam Pembangunan Fisik (Studi Analisis Kebijakan Pemerintah Desa). Unigal, 2(1), 28-39.

Sembel, T., Gosal, R., \& Pangemanan, S. (2017). Partisipasi Masyarakat Dalam Pembangunan Desa (Studi di Desa Sinsingon Barat Kecamatan Passi Timur Kabupaten Bolaang Mongondow). Eksekutif, 2(1). https://ejournal.unsrat.ac.id/index.php/jurnaleksekutif/article/viewFile/16194/15698

Setiawan, F., \& Saefulloh, A. (2019). Kolaborasi Yang Dilaksanakan Di Kawasan Wisata Dermaga Kereng Bangkirai Kota Palangka Raya. Administratio: Jurnal Ilmiah Administrasi Publik Dan Pembangunan, 10(2), 71-80. https://doi.org/10.23960/administratio.v10i2.95

Subekti, T. (2014). Partisipasi Politik Masyarakat Dalam Pemilihan Umum (studi Trun of Voter dalam Pemilihan Umum Kepala Daerah Kabupaten Magetan Tahun 2013). Partisipasi Politik Masyarakat Dalam Pemilihan Umum, 1.

Tilaar, H. (2009). Kekuasaan dan Pendidikan: Kajian Manajemen Pendidikan Nasional dalam Pusaran Kekuasaan. Rinika Cipta. 